\title{
Acquired Antibody-Mediated Pure Red Cell Aplasia Following Treatment With Darbepoetin
}

\section{Dear Editor,}

Pure red cell aplasia (PRCA) is a syndrome defined by normocytic normochromic anaemia with severe reticulocytopaenia and marked reduction or absence of erythroid precursors from the bone marrow. Secondary acquired PRCA may be associated with systemic disorders such as autoimmune disorders, lymphoproliferative disorders, infections such as B19 parvovirus infections or non-haematologic neoplasms such as thymomas, drugs and toxic agents. ${ }^{1-3}$ PRCA associated with the use of erythropoiesis stimulating agents (ESAs) is a rare complication that was first described in 1998. Recombinant deoxyribonucleic acid (DNA) technology is used in the production of exogenous erythropoietin (EPO). This technique can incite antibody $(\mathrm{Ab})$ production that can neutralise the agent's therapeutic function, affecting efficacy, pharmacokinetic and pharmacodynamics. ${ }^{4}$ Most of the initially reported cases occurred with epoetin alpha. Subsequent cases have since been reported with other commercially available ESAs. ${ }^{5}$ Despite this, darbepoetin, a second-generation ESA, has rarely been described in the growing literature to be a cause of Ab-mediated PCRA. Compared to epoetin alpha, darbepoetin has additional carbohydrate chains and salic acid residues. These features are said to make it more resistant to $\mathrm{Ab}$ formation.

Here, we report a case of proven Ab-mediated PRCA in a non-dialysis patient who received darbepoetin(Arasnesp, Kyowa Hakko Kirin, Chiyoda-ku, Tokyo, Japan) as a single ESA. She responded to treatment involving the cessation of darbepoetin as well as the use of immunosuppressants (prednisolone and cyclophosphamide) with resultant improvement in anaemia and reticulocyte counts.

\section{Case Report}

A 63-year-old Indian female with stage 3 chronic kidney disease (CKD) secondary to diabetic kidney disease, was started on fortnightly subcutaneous darbepoetin as treatment for anaemia of CKD. She initially responded well to darbepoetin with her haemoglobin $(\mathrm{Hb})$ level rising from a pretreatment level of $8 \mathrm{~g} / \mathrm{dL}$ to $10 \mathrm{~g} / \mathrm{dL}$. However, she next presented to the hospital with symptomatic anaemia-postural giddiness, decreased effort tolerance and pallor-10 months after ESA treatment. There were no bleeding manifestations. Laboratory results revealed a microcytic, iron replete anaemia with impaired reticulocyte response without suggestion of haemolysis ( $\mathrm{Hb}$ of $4.9 \mathrm{~g} / \mathrm{dL}$ with a mean corpuscular volume of $72.3 \mathrm{fl}$ and a reticulocyte count of $0.21 \%$ [absolute reticulocyte count, $2.1 \times 10^{9} / \mathrm{L}$ ]). Her oesophagogastroduodenoscopy and colonoscopy results were normal. A bone marrow aspirate demonstrated an absence of erythroid precursors, consistent with a diagnosis of PRCA. An extensive work-up for other secondary causes for PRCA was unrevealing for any other causes. These included screening for paroxysmal nocturnal haematuria, autoimmune causes (complement levels 3 and 4, anti-double stranded DNA, anti-nuclear Ab), underlying malignancy with computerised tomography of the neck, thorax, abdomen and pelvis as well as screening for infections such as hepatitis B, hepatitis C, human immunodeficiency virus, cytomegalovirus, Epstein-Barr virus and parvovirus.

Darbepoetin therapy was discontinued and she was discharged following symptomatic treatment with blood transfusions. Subsequently, results from serological studies confirmed the presence of anti-darbepoetin alfa and anti-epoetin alfa $\mathrm{Ab}$. The assays were performed at the Kyowa Hakko Kirrin Co Ltd laboratory and the radioimmunoprecipitation method was used in the detection of Abs. She was started on daily prednisolone $1 \mathrm{mg} / \mathrm{kg}$ and cyclophosphamide $50 \mathrm{mg}$ daily, with recovery of $\mathrm{Hb}(9.0 \mathrm{~g} / \mathrm{dL})$ and reticulocyte counts $(1.9 \%$, absolute reticulocyte count of $\left.60.7 \times 10^{9} / \mathrm{L}\right)$ after 6 months of treatment. Immunosuppression was gradually weaned, with cyclophosphamide stopped on 4 October 2015 and prednisolone on 21 February 2016.

\section{Discussion}

The incidence of Ab-mediated PRCA has increased with the growing use of ESA as a treatment for anaemia in CKD. It remains a significant cause of ESAresistance and profound transfusion-dependent anaemia. The pathogenesis involves the development of neutralising anti-EPO Abs which are active regardless of ESA dose. ${ }^{6}$ These Abs cross-react with different ESAs, negating alternative ESAs as therapeutic 
options. Given that ESA represents the mainstay of therapy for anaemia of chronic renal disease, alternative treatment strategies are desperately needed. ${ }^{6} \mathrm{Ab}$-mediated PRCA is a diagnosis of exclusion and other common causes of PRCA need to be ruled out first. It is characterised by severe anaemia, reticulopaenia, absence of erythroid precursors within the bone marrow ( $<5 \%$ erythroblasts) and proven anti-EPO Abs in the serum of patients with exposure to at least 3-4 weeks of ESA. ${ }^{7,8}$ Management involves treatment of symptomatic anaemia, cessation of all ESA products and immunosuppression. ${ }^{9}$ The majority of reports of proven PRCA are associated with epoetin alfa or epoetin beta. However, there have been limited reports of proven
PRCA associated with the use of darbepoetin including 2 case reports and 1 case identified from a recent prospective registry study (Table 1) ${ }^{10-12}$ Our patient fulfilled the criteria of Ab-mediated PRCA with proven presence of neutralising Abs and absence of other associated causes.

\section{Conclusion}

ESA-induced PRCA-although rare-remains a significant cause of morbidity. The current case reflects that while rare, darbepoetin can also induce PRCA and should be considered in the differentials for patients who develop loss of or lack of response of anaemia following its use.

Table 1. Summary of Case Reports on Darbepoetin-Related Pure Red Cell Aplasia

\begin{tabular}{|c|c|c|c|c|c|c|}
\hline Author & $\begin{array}{c}\text { Number of } \\
\text { Cases }\end{array}$ & Type of Case & Ab Proven & Type of Ab & $\begin{array}{c}\text { Response to } \\
\text { Treatment }\end{array}$ & $\begin{array}{c}\text { Treatment } \\
\text { Administered }\end{array}$ \\
\hline Jacob et $\mathrm{al}^{*}$ & 1 & $\begin{array}{l}\text { Dialysis, end-stage } \\
\text { renal failure }\end{array}$ & Yes & Anti-EPO Ab & No & $\begin{array}{l}\text { Prednisolone (followed } \\
\text { by intravenous } \\
\text { immunoglobulin), } \\
\text { ciclosporin, prednisolone } \\
\text { and cyclophosphamide }\end{array}$ \\
\hline Howman et $\mathrm{al}^{\dagger}$ & 1 & $\begin{array}{c}\text { Non-dialysis, } \\
\text { CKD } \\
\text { stage } 4\end{array}$ & Yes & $\begin{array}{c}\text { Anti-darbepoetin } \\
\text { alfa and } \\
\text { anti-EPO Ab }\end{array}$ & Yes & $\begin{array}{c}\text { Cyclophosphamide } \\
(100 \mathrm{mg}) \text { and prednisolone } \\
(50 \mathrm{mg}) \text { every morning as } \\
\text { starting dose with gradual } \\
\text { tapering. Recovery within } 4 \\
\text { weeks of treatment }\end{array}$ \\
\hline Macdougall et $\mathrm{al}^{\ddagger}$ & 1 & $\begin{array}{l}\text { Non-dialysis, } \\
\text { CKD stage } 3\end{array}$ & Yes & Anti-EPO Ab & Yes & Prednisolone \\
\hline
\end{tabular}

Ab: Antibody; CKD: Chronic kidney disease; EPO: Erythropoietin

"Jacob A, Sandhu K, Nicholas J, Jones H, Odum J, Rylance P, et al. Antibody-mediated pure red cell aplasia in a dialysis patient receiving darbepoetin alfa as the sole erythropoietic agent. Nephrol Dial Transplant 2006;21:2963-5.

†Howman R, Kulkarni H. Antibody-mediated acquired pure red cell aplasia (PRCA) after treatment with darbepoetin. Nephrol Dial Transplant 2007;22:1462-4.

Macdougall IC, Casadevall N, Locatelli F, Combe C, London GM, Di Paolo S, et al. Incidence of erythropoietin antibody-mediated pure red cell aplasia: the Prospective Immunogenicity Surveillance Registry (PRIMS). Nephrol Dial Transplant 2015;30:451-60.

\section{REFERENCES}

1. Kueh YK, Choo MH. Reversible pure red cell aplasia associated with diphenylhydantoin therapy. Ann Acad Med Singapore 1991;20:407-9.

2. Kueh YK, Sng I, RauffA. Reversal of red cell aplasia and marrow fibrosis in non-Hodgkin's lymphoma. Ann Acad Med Singapore 1983;12:472-3.

3. Means RT Jr. Pure red cell aplasia. Blood 2016;128:2504-9.

4. Thorpe R, Swanson SJ. Current methods for detecting antibodies against erythropoietin and other recombinant proteins. Clin Diagn Lab Immunol 2005;12:28-39.
5. Pollock C, Johnson DW, Horl WH, Rossert J, Casadevall N, Schellekens $\mathrm{H}$, et al. Pure red cell aplasia Induced by erythropoiesis-stimulating agents. Clin J Am Soc Nephrol 2008;3:193-9.

6. Casadevall N. Pure red cell aplasia and anti-erythropoietin antibodies in patients treated with epoetin. Nephrol Dial Transplant 2003;18 Suppl 8:viii37-41.

7. Rossert J, Casadevall N, Eckardt KU. Anti-erythropoietin antibodies and pure red cell aplasia. J Am Soc Nephrol 2004;15:398-406.

8. Bennett CL, Cournoyer D, Carson KR, Rossert J, Luminari S, Evens $\mathrm{AM}$, et al. Long-term outcome of individuals with pure red cell aplasia 
and antierythropoietin antibodies in patients treated with recombinant epoetin: a follow-up report from the Research on Adverse Drug Events and Reports (RADAR) Project. Blood 2005;106:3343-7.

9. Sawada K, Fujishima N, Hirokawa M. Acquired pure red cell aplasia: updated review of treatment. Br J Haematol 2008;142:505-14.

10. Jacob A, Sandhu K, Nicholas J, Jones H, Odum J, Rylance P, et al. Antibody-mediated pure red cell aplasia in a dialysis patient receiving darbepoetin alfa as the sole erythropoietic agent. Nephrol Dial Transplant 2006;21:2963-5.

11. Howman R, Kulkarni H. Antibody-mediated acquired pure red cell aplasia (PRCA) after treatment with darbepoetin. Nephrol Dial Transplant 2007;22:1462-4

12. Macdougall IC, Casadevall N, Locatelli F, Combe C, London GM, Di Paolo S, et al. Incidence of erythropoietin antibody-mediated pure red cell aplasia: the Prospective Immunogenicity Surveillance Registry (PRIMS). Nephrol Dial Transplant 2015;30:451-60.
Charmaine SM $\underline{\text { Sia }},{ }^{1} M B B S, M R C P$, MMed,

Wei Ying Jen, ${ }^{2}{ }_{B M B C h, M C R P, M M e d}$,

Michelle LM Poon, ${ }^{2}$ MBBS, MRCP, FRCPath (UK)

'Division of Nephrology, University Medical Cluster, National University Health System, Singapore

${ }^{2}$ Department of Hematology-Oncology, National University Cancer Institute, Singapore

Address for Correspondence: Dr Charmaine Sia Si Min, Division of Nephrology, University Medical Cluster, National University Health System, Level 10 NUHS Tower Block, 1E Kent Ridge Road, Singapore 119228. Email: Charmaine_sia@nuhs.edu.sg 